\title{
Letter Report: \\ Media Information Review, 1991
}

\section{G. L. Harvey}

April 1992
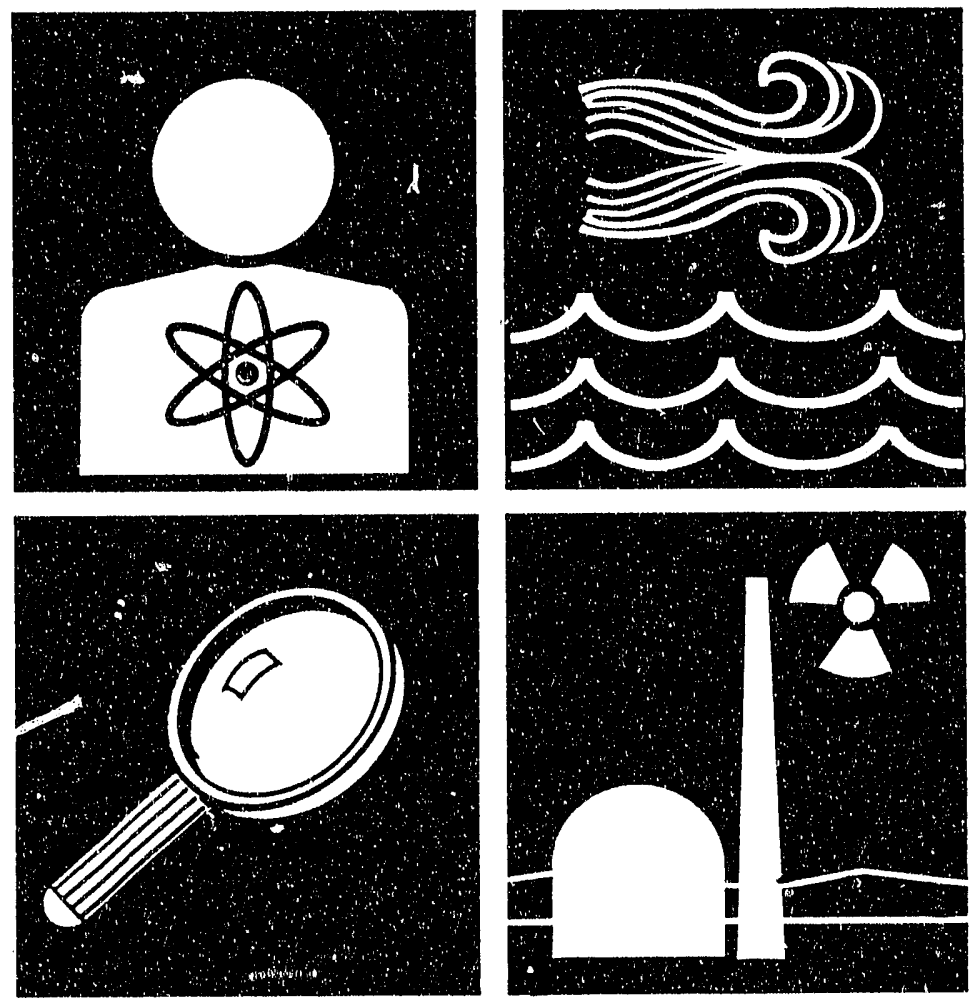

Prepared for the Technical Steering Panel

$\%$ Battelle 


\section{DISCLAIMER}

This report was prepared under the direction of the HANFORD ENVIRONMENTAL DOSE RECONSTRUCTION PROJECT Technical Steering Panel by Battelle Memorial Institute's Pacific Northwest Laboratories operating the Pacific Northwest Laboratory for the U.S. Department of Energy (DOE). While funding for the work was provided by DOE, the work is not under DOE direction or control. The views and opinions of the authors expressed in this document do not necessarily reflect those of the United States Government or any agency thereof. Reference herein to any specific commercial product, process or service by trade name, trademark, manufacturer or otherwise does not necessarily constitute or imply its endorsement, recommendation or favoring by the U.S. Government or any agency thereof, nor by Battelle Memorial Institute.

Printed in the United States of America

Available to DOE and DOE contractors from the

Office of Scientific and Technical Information, P.O. Tiox 62, Oak Ridge, TN 37831; prices available from (615) $576-8401$, ETS 626-\$3401.

Available to the public from the National Technical Information Service, U.S. Department of Commerce, 5285 Port Royal Rd., Springrield, VA 22161. 
PNL- $-8071-\mathrm{HEDR}$

DE92 013273

MEDIA INFORMATION REVIEW, 1991

Hanford Environmental

Dose Reconstruction Project

G. L. Harvey

Apri1 1992

Letter report

to the Technical Steering Panel

Pacific Northwest Laboratory

Richland, Washington 99352 


\section{CONTENTS}

PURPOSE AND BACKGROUND . . . . . . . . . . . . . . . . . . . 1

COMPARISON WITH PREVIOUS REPORT . . . . . . . . . . . . . . . . 1

FINDINGS . . . . . . . . . . . . . . . . . . . 2

ARTICLES REVIEWED AND CATEGORIZED . . . . . . . . . . . 2

ISSUES ....................... 3

APPENDIX - MEDIA INFORMATION REVIEW, JANUARY - JULY, 1991 . . . . A.1 


\section{PURPOSE AND BACKGROUND}

The media information review, requested by the Communications Subcommittee of the Technical Steering Panel (TSP), provides a general indication of the media's areas of interests with regard to the Hanford Environmental Dose Reconstruction (HEDR) Project. This review briefly assesses 24 newspaper and magazine articles collected between September 1991 and January 1992 by Pacific Northwest Laboratory (PNL). Articles that mention the project, activities closely associated with it, or members of the Panel were included in the analysis. Attempts were made to identify general categories and issues found within the articles and display the results in an order of ranking. This review is unscientific and is not meant to display a technical analysis of the materials.

\section{COMPARISON WITH PREVIOUS REPORT}

A similar media information review was prepared in August 1991 (see Appendix) at the request of the TSP Communications Subcommittee. The sample of articles collected in the Appendix included approximately 60 entries. That report reflected articles collected during a 7 -month period (January through July 1991), where this report considers only 24 articles collected during 5 months.

The previous report included a significant number of articles emphasizing Idaho, the Lewiston TSP meeting, and a series of Hanford-related stories written by the Lewiston Tribune. Other areas of interest, including the Hanford Thyroid Disease Study (HTDS) and the project's transfer from the U. S. Department of Energy (DOE) to Centers for Disease Control (CDC), contributed to the larger number of stories. The current report evaluates articles that reflect more traditional issues that have been associated with the project for the past several years (e.g., "downwinders" and oversight groups, legal issues, and related studies).

Not unlike the previous report (see Appendix), allegations of health effects and distrust of the federal government were the primary areas as reported by the media both by ranking of the number of stories written and by 
number of column inches devoted to those stories. Most of the mentions of distrust and negative health effects originated from stories related to dowriwinders.

\section{FINDINGS}

This review identified no particular surprises, nor revealed areas where the media is showing unusual concerns, misinterpreting findings, or confusing issues. The media focused its most significant attention during the review. period on

- approval of funding for the Hanford Health Information Network (HHIN) and naming of its appointees

- forming of the Hanford Downwinder Health Concerns Group

- awarding of a $\$ 50,000$ grant by Congress to Portiand State University to study cancer death rates on soldiers stationed at Hanford during and after World War II, and

- dismissal of a series of claims by a federal judge in a class action lawsuit filed by Hanford downwinders.

\section{ARTICLES REVIEWED AND CATEGORIZED}

General categories (topics) are listed, followed by the total column inches devoted to that category (e.g., Panel Members - $70 \mathrm{c} / \mathrm{in}$ ). Under each category are articles, in that category, followed by column inches, date and source $^{(a)}$ (e.g., 10 [c/in]-12/28 [December 28]/ST [Seatt]e Times]).

\section{Panel Members - $70 \mathrm{c} /$ in}

J. Till on woink at Fernald (6-12/19, TCH)

Norma Jean Germond (64-1/16, Ore)

Legal/Litigation - $64 \mathrm{c} /$ in

Federal judge dismisses claims (14-10/24, TCH)

Lawsuit ruling expected in two weeks $(29-10 / 4, \mathrm{TCH})$

(a) Sources: NYT (New York Times), Ore (Oregonian), ST (Seattle Times), SR (Spokesman Review), and TCH (Tri-City Herald). 
Delay of downwinders law suits (21-10/4, SR)

Hanford Health Information Network - $62 \mathrm{c} /$ in

Dr. Richard Belsey on HHIN/HEDR (15-11/10, SR)

Appointees named (4-11/2, SR)

Appointees named $(8-11 / 2, \mathrm{TCH})$

Funding announced for HHIN (11-9/21, Ore)

HHIN project $O K^{\prime} d(11-9 / 20, S R)$

Health network approved (13-9/20, TCH)

Downwinders/Oversight Groups - $52 \mathrm{c} /$ in

Downwinders share 171 ness tales (18-12/28, SR)

New group - Hanford Downwinders Health Concerns (7-12/23, ST)

New group - Hanford Downwinders Health Concerns (8-12/23, TCH)

New group tackles health concerns (7-12/23, Ore)

Gertie Hanson story $(12-12 / 2, S R)$

Various Stories - $46 \mathrm{c} /$ in

TSP video available $(3-12 / 20, \mathrm{TCH})$

Uranium dust at Fernald [J. Ti]1 mention] (13-12/19, NYT)

TSP to meet in Walla Walla $(3-10 / 3, \mathrm{TCH})$

New info released on "green run" (27-9/25, TCH)

other Studies $-32 \mathrm{c} /$ in

Grant approved for study of Hanford soldiers (6-12/2, ST)

Grant approved for study of Hanford soldiers (6-12/2, TCH)

Grant approved for study of Hanford soldiers (7-12/1, SR)

Expect health surprises [Hanford Thyroid Disease Study (HTDS)]

$(13,10 / 11, \mathrm{TCH})$

\section{ISSUES}

The following lists address the issues found within the articles reviewed. There may be several issues found within each article (e.g., distrust and health effects; legal and downwinders). 


\section{Ranked by Number of Stories}

1. Health Effects Allegations - 10 stories, $92 \mathrm{c} /$ in

2. Distrust of Federal Government - 9 stories, $113 \mathrm{c} /$ in

3. Hanford Health Information Network - 6 stories, $62 \mathrm{c} /$ in

4. (a) General - 5 stories, $83 \mathrm{c} /$ in

5. (a) Downwinder/Oversight Issues - 5 stories, $52 \mathrm{c} /$ in

6. (a) Other Studies (Primarily HTDS) - 5 stories, $50 \mathrm{c} /$ in

i. Legal - 3 stories, $64 \mathrm{c} / \mathrm{in}$

Ranked by Total Column Inches

1. Distrust of Federal Government - $113 \mathrm{c} /$ in, 9 stories,

2. Health Effects Allegations - $92 \mathrm{c} / \mathrm{in}, 10$ stories

3. General - $83 \mathrm{c} / \mathrm{in}, 5$ stories

4. Legal - $64 \mathrm{c} / \mathrm{in}, 3$ stories

5. Hanford Health Information Network - $62 \mathrm{c} /$ in, 6 stories

6. Downwinder/Oversight Issues - $52 \mathrm{c} / \mathrm{in}, 5$ stories

7. Other Studies (Primarily HTDS) - $50 \mathrm{c} /$ in, 5 stories
(a) $t=$ tied. 
APPENDIX

MEDIA INFORMATION REVIEW, JANUARY - JULY 1991 
APPENDIX

MEDIA INFORMATION REVIEW, JANUARY - JULY 1991

This media information review briefly assesses the newspaper and magazine articles collected between January 1 and July 18, 1991 by PNL. Attempts were made to identify general caiegories and issues found within the articles and display the results in an order of ranking. This review was unscientific and is not meant to display a technical analysis of the materials.

\section{ARTICLES REVIEWED AND CATEGORIZED}

The categories are followed by total column inches (e.g., Idaho - 188 c/in). The articles are followed by column inches and date (e.g., 10 [c/in]4/6 [April 6, 1991]). Same or similar stories run in several papers may be listed for each article.

\section{Downwinders/Oversight Groups - $207 \mathrm{c} /$ in}

HEAL as watchdog $(10-4 / 6)$

Downwinders similar to Marshall Is land - (7-4/9)

Downwinders group founded $(5-3 / 6)$

Downwinder distrust (25-2/27)

Downwinders distrust, loosing faith $(30-2 / 10)$

Downwinders (HHIN) medical and information referral service (11-5/4)

Downwinder praised, PI award - (5-1/25)

Lois Camp, Lacrosse, disirust, secrecy (40-1/27)

Past releases, Green Run, legal/compensation - (25-1/91)

Drop study and give money to people affected - $(8-2 / 12,10-2 / 12)$

Downwinders push for 'nuclear ethics' law (12-7/18, 14-1/18)

Idaho $-188 \mathrm{c} / \mathrm{in}$

Meeting $(8-4 / 3)$

Meeting $(10-4 / 22)$

Idaho may be included in study and determine exposure (10-4/6)

Radiation reports conflict (Idaho)- (11-5/31, 12-5/31)

A. 1 
I-129-(30-5/31)

Secrecy/past history on Idaho - $(36-5 / 31)$

Hanford knew of high levels of $\mathrm{rad}(9-5 / 31)$

Idaho weathermen monitoring - (20-5/31)

Wind patterns and disposition of various rad (38-5/31)

Editorial - Gerdi Hanson, Idaho's lack of involvement (4-1/11)

HTDS - $130 \mathrm{c} /$ in

Study won't link radiation and disease (10-3/1)

HTDS faces obstacles - (20-2/28)

Study is a sham, won't confirm or dismiss health allegations (12-2/20, $8-2 / 20,40-2 / 19)$

Study to begin at end of year $(18-7 / 10,10-7 / 10,12-7 / 11)$

$\underline{C D C-85 c / i n}$

Study goes to $\operatorname{CDC}(8-1 / 11)$

Transfer of nationwide studies to DHHS $(20-1 / 7,4-1 / 6,5-1 / 5,18-1 / 5$,

$12-1 / 3,8-1 / 3,10-1 / 8)$

General/Varied - $80 \mathrm{c} / \mathrm{in}$

Hanford Releases Overstated - (5-4/6)

Yalow critical of I-131 study - (28-3/16)

Radiation, neutral story $(40-2 / 19)$

Editorial - against HEAL/downwinders (4-2/17)

Society for Prof Journalists, TSP involvement (3-1/6)

Panel Members - $59 \mathrm{c} /$ in

Article on J. Til1 (8-4/6)

V. Nguyen - panelist defrauds government $(5-4 / 10,8-4 / 11,9-4 / 11,6-4 / 11$, 6-4/11)

Connell meeting (positive story of support) (10-7/12)

Public meetings $(3-7 / 10)$

Native Americans $-45 \mathrm{c} /$ in

$N A^{\prime} s$ ifestyle affected (15-3/2)

Colvilles want role in studies $(15-2 / 27)$ 
Tribes to sign contracts $(5-1 / 20,10-1 / 11)$

Legal $-23 c /$ in

Judge order merging of suits (8-3/2)

Long court battles to begin $(15-2 / 17)$

Budget Issues - $15 \mathrm{c} /$ in

Budget policies (15-1/12)

The following section addresses the issues found within the articles reviewed. There may be several issues found within each article (e.g., distrust, legal/lawsuits and compensation).

\section{ISSUES}

\section{Ranked by Stories}

1. Health effects allegations - 16 stories, $248 \mathrm{c} /$ in

2. Distrust - 15 stories, $274 \mathrm{c} /$ in

Lack of DOE credibility (not TSP's)

3. General - 9 stories, $76 \mathrm{c} /$ in

TSP's communications role

4. Other studies (HTDS) - 8 stories, $130 \mathrm{c} /$ in

5. Technical Stories - 3 stories, $78 \mathrm{c} /$ in

6. Transfer to CDC - 7 stories, $77 \mathrm{c} /$ in

7. V. Nguyen - 5 stories, $34 \mathrm{c} /$ in

8. Legal/Lawsuits - 5 stories, $63 \mathrm{c} /$ in

9. Compensation - 3 stories, $83 \mathrm{c} /$ in

10. Uncertainty - 2 stories, $33 \mathrm{c} /$ in

Questionable need for study

11. Budget - 1 story, $15 \mathrm{c} /$ in 


\section{Ranked by Column Inches}

1. Distrust - 15 stories, $274 \mathrm{c} /$ in Lack of DOE credibility (not TSP's)

2. Health Effects Allegations - 16 stories, $248 \mathrm{c} /$ in

3. Other Studies (HTDS) - 8 stories, $130 \mathrm{c} /$ in

4. Compensation - 3 stories, $83 \mathrm{c} /$ in

5. Technical Stories - 3 stories, $78 \mathrm{c} /$ in

6. Transfer to CDC -7 stories, $77 \mathrm{c} /$ in

7. General - 9 stories, $76 \mathrm{c} /$ in TSP's communications role

8. Legal/Lawsuits .. 5 stories, $63 \mathrm{c} /$ in

9. V. Nguyen - 5 stories, $34 \mathrm{c} /$ in

10. Uncertainty - 2 stories, $33 \mathrm{c} /$ in Questionable need for study

11. Budget - 1 story, $15 \mathrm{c} /$ inl 


\section{DISTRIBUTION}

No. of

Copies

\section{OFFSITE}

Technical Steering Panel

D. S. Barth

University of Nevada

4505 Maryland Parkway

Las Vegas, NV 89154

W. A. Bishop

2503 Wedgewood Court S.E.

01ympia, WA 98501

M. L. Blazek

Oregon Department of Energy

625 Marion Street N.E.

Salem, OR 97310

G. G. Caldwell

Director

Tulsa City-County Health Dept

4616 East 15th Street

Tulsa, OK 74112

S. N. Davis

Dept. of Hydrology \& Water Resources

Building 11

University of Arizona

Tucson, AZ 85721

N. J. Germond

224 Iron Mountain Blvd.

Lake Ozwego, OR 97034

P. C. Ki ingeman

Civil Engineering Dept.

Appejin Hall 202

Oregon State University

Corvallis, OR 97331-2302
No. of

Copies

K. J. Kopecky

Fred Hutchinson Cancer

Research Center

1124 Columbia Street

Seattle, WA 98104

P. D. McGavran

Dept. of Health and Welfare

450 W. State Street, 4 th Floor

Boise, ID 83720-5450

R. L. Morrill

Dept. of Geography, DP-10

University of Washington

Seattle, WA 98195

A. H. Murphy

Dept. of Atmospheric Sciences

Oregon State University

Corvallis, OR 37331-2209

D. W. Price

Agricultural Economics

Hulbert Hall Room 211

Washington State University

Puliman, WA 99164-6210

M. A. Robkin

Radiological Sciences, SB-75

University of Washington

Seattle, WA 98195

G. S. Roessier

202 Nuclear Sciences Center

University of Florida

Gainsville, FL 32611

B. Shleien

2421 Homestead Drive

Silver Springs, MD 20902 
No. of

Copies

A. P. Slickpoo, Sr.

809 Nez Perce Lane

P.0. Box 331

Kamiah, ID 83536

J. E. Ti11

Route 2 Box 122

Neeses, SC 29107

D. E. Walker, Jr.

P.0. Box 4147

Boulder, CO 80306

other

2 DOE Office of Scientific and Technical Information

Technical Information Center

P.0. Box 62

Oak Ridge, TN 37830

B. G. Brooks, EH- 4 ?]

Department of Energy

Room J-112

Germantown, MD 20545

18 K. Charlee

Office of Nuclear Waste Mgmt.

Department of Ecology

719 Sleater Kinney Road, S.E.

Suite 200

Olympia, WA 98504

W. A. Glass

13874 E. 47th Lane

Yuma, $A Z 85365$

M. Sage

Centers for Disease Control

$1600 \mathrm{Cl}$ ifton Road

Atlanta, GA 30333
No. of

Copies

J. Thomas

HEAL

1720 N. Ash

Spokane, WA 99205

\section{ONSITE}

7 DOE Richland Field Office

R. F. Brich, TSD

A5- 55

M. W. Tiernan, TSD

A5- 55

Public Reading Room (5) A1-65

29 Pacific Northwest Laboratory

J. M. Daer (5)

K6- 89

D. H. Denham

A3 -60

R. L. Dirkes

W. T. Farris

M. D. Freshley

R. 0. Gilbert

G. L. Harvey (5)

C. M. Heeb

T. A. Ikenberry

$\mathrm{K} 6-13$

K3-54

$\mathrm{K} 6-77$

K7-34

K1-36

K6-42

A. H. McMakin

B. A. Napier

K3-54

J. V. Ramsdell

K3-54

D. B. Shipler

D. L. Stewart

K6- 03

K6- 89

W. L. Templeton

K5-91

$\mathrm{K} 1-30$

W. H. Walters

K6-77

G. L. Wilfert

$K 6-54$

Publishing Coordination

Records Center

$\mathrm{K} 1-06$

$\mathrm{K} 3-70$

Technical Library (2)
P8-55 

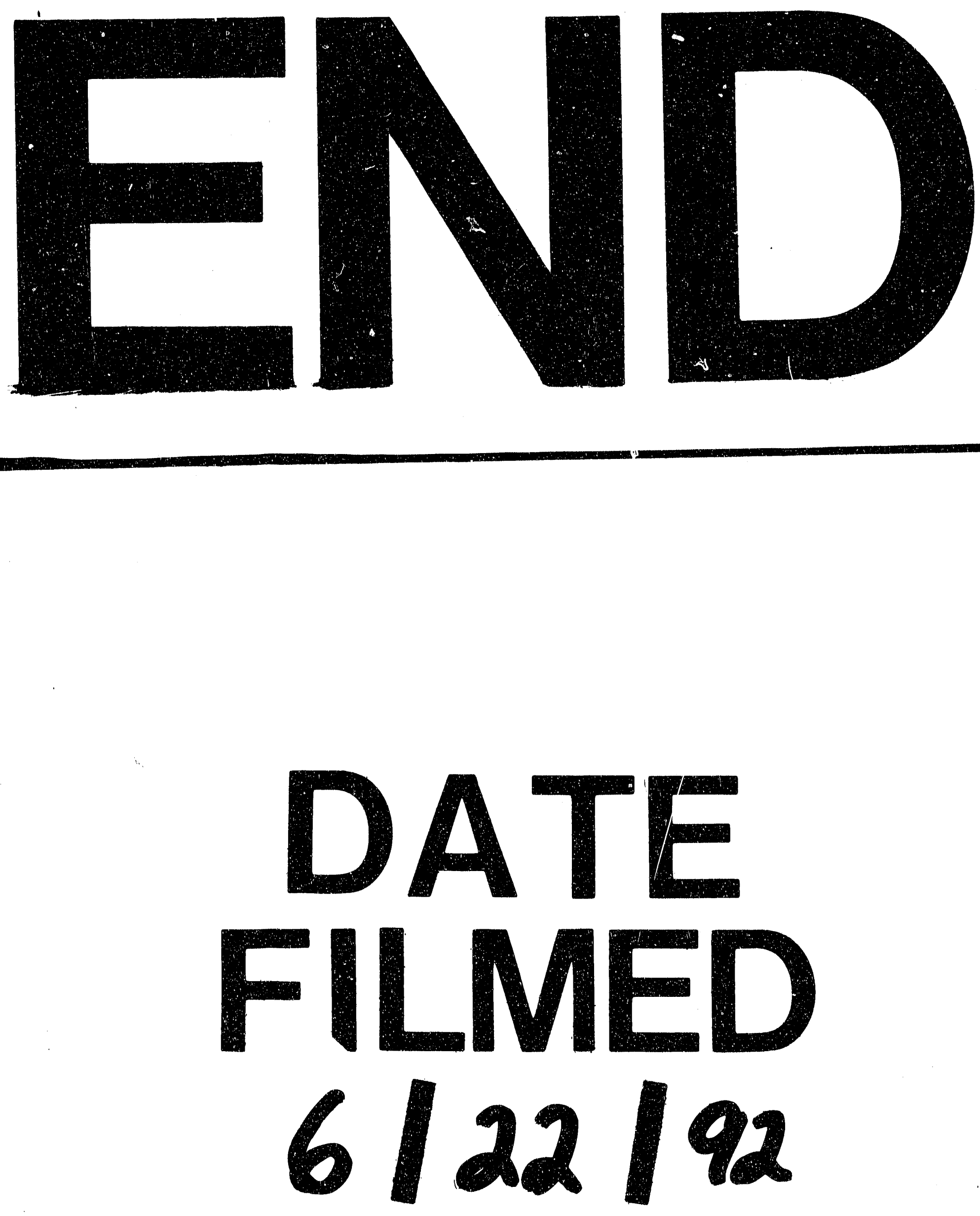
